\title{
Vage Normen sebagai Sumber Hukum Diskresi yang Belum Diterapkan oleh Polisi Penyidik Anak
}

\author{
Abintoro Prakoso \\ Fakultas Hukum Universitas Negeri Jember \\ Jl. Kalimantan No. 37 Jember Jawa Timur \\ kukuhbudimulya@yahoo.com
}

\begin{abstract}
The research is focused on the implementation of vage normen as a discretion law source done by children police penyidik and on the kind of crimes done by children that can be discrete. The method used is the normative legal research through literature that is a research for secondary data as law material. The result proves that the police discreet taken from vage normen is not implemented yet as there is no clear rules about it. the kind of children crimes that may be discreet are clash, stealing, money game, vandalism, dangerous burning for others' property, stealing, smuggling, crime trial, passing on stolen's goods, destruction, public means destruction, destroying things, rascals, breaking traffic regulation, dangerous fireworks, being truant, running away from home, psychotropic involve, traffic accident's suspect, hanging out over midnight, breaking personal rules and smoking.
\end{abstract}

Key words : Vage normen, discretion, investigation, non juridic, well-being of the juvenile

\begin{abstract}
Abstrak
Penelitian ini mengkaji tentang penerapan vage normen sebagai sumber hukum diskresi oleh polisi penyidik anak dan jenis-jenis tindak pidana apa yang dilakukan oleh anak yang dapat didiskresi. Metode pendekatan dalam penelitian ini pendekatan hukum normatif (legal research) yang merupakan penelitian kepustakaan yaitu penelitian terhadap data sekunder yang berupa bahan hukum. Hasil penelitian ini menyimpulkan, kewenangan diskresi pada polisi yang bersumber pada vage normen secara umum belum atau tidak diterapkan karena belum jelas peraturan perundang-undangannya. Jenis-jenis tindak pidana anak yang memungkinkan untuk didiskresi adalah sebagai berikut; tawuran, pencurian ringan, permainan uang tanpa unsur perjudian; perusakan barang secara terbuka atas barang pribadi secara terbuka (vandalisme); pembakaran yang membahayakan barang; pencurian tanpa membobol rumah; penggelapan barang; percobaan melakukan tindak pidana ringan; penadahan; pembinasaan atau perusakan barang, termasuk pencorengan saran publik; merusak barang; berandalan; pelanggaran lalu lintas; menyulut petasan yang membahayakan lingkungan umum; membolos sekolah; melarikan diri dari rumah; tersangkut kasus obat-obatan terlarang; tersangkut atau pelaku kecelakaan lalu lintas. Keluyuran setelah tengah malam; pelanggaran yang tidak menyangkut kepentingan umum dan merokok.
\end{abstract}

Kata kunci : Ketidakjelasan aturan, diskresi, penyelidikan, non-hukum, keberadaan anak-anak di bawah umur. 


\section{Pendahuluan}

Di kota-kota besar dengan problema sosial dan ekonomi, yang mengakibatkan bertambahnya jumlah anak yang terlantar. Anak terlantar dan anak nakal, bila jumlahnya cukup besar merupakan hambatan dalam perjuangan mencapai cita-cita bangsa. Karena itu maka perlu dengan sungguh-sungguh dipikirkan diselenggarakannya suatu peradilan anak yang bertujuan terlaksananya keadilan serta mengarahkan pengembangan pribadi anak demi kesejahteraan anak itu sendiri dan kepentingan masyarakat. Berikut ini disajikan jumlah kasus-kasus anak yang disangka melakukan tindak pidana.

Sepanjang tahun 2000 tercatat dalam statistik kriminal kepolisian terdapat lebih dari 11.344 anak yang disangka sebagai pelaku tindak pidana. Pada Januari hingga Mei 2002, ditemukan 4.325 tahanan anak di rumah tahanan dan Lembaga Pemasyarakatan diseluruh Indonesia. Lebih menyedihkan, sebagian besar $(84,2 \%)$ anakanak itu berada di dalam lembaga penahanan dan lembaga pemenjaraan untuk orang-orang dewasa. Jumlah anak-anak yang ditahan tersebut, tidak termasuk anakanak yang ditahan dalam kantor polisi. Pada rentang waktu yang sama yaitu pada Januari hingga Mei 2002, tercatat 9.465 anak-anak yang berstatus sebagai anak didik (anak sipil, anak negara dan anak pidana) tersebar di seluruh rumah tahanan dan Lembaga Pemasyarakatan. Sebagian besar, yaitu 53,3\% berada di rumah tahanan dan Lembaga Pemasyarakatan untuk orang dewasa. Kondisi ini tentu sangat memprihatinkan, karena banyak anak-anak yang harus berhadapan dengan proses peradilan. Keberadaan anak-anak dalam tempat penahanan dan pemenjaraan bersama orang dewasa menempatkan anak pada situasi rawan menjadi korban berbagai tindak kekerasan. ${ }^{1}$

Kasus di atas menunjukkan adanya pelanggaran terhadap Pasal 44 ayat (6) Undang-undang No. 3 Tahun 1997 tentang Pengadilan Anak, yang menyebutkan bahwa: penahanan terhadap anak dilaksanakan di tempat khusus untuk anak di lingkungan Rumah Tahanan Negara, Cabang Rumah Tahanan Negara, atau di tempat tertentu. Namun kenyataannya anak ditahan bersama-sama dengan tahanan orang dewasa.

${ }^{1}$ Mamik Sri Supatmi Purnianti dan Ni Made Martini Tinduk, Analisa Sistem Peradilan Pidana Anak Juvenile Justice System) di Indonesia, UNICEF, Indonesia, 2003, hlm. ii 
Dalam Undang-Undang No. 2 Tahun 2002 tentang Kepolisian Negara Bagian Penjelasan Umum menyebutkan bahwa setiap pejabat Kepolisian Negara Republik Indonesia memiliki kewenangan diskresi, yaitu kewenangan untuk bertindak demi kepentingan umum berdasarkan penilaian sendiri.

Secara teoritik wewenang yang bersumber dari peraturan perundang-undangan tersebut diperoleh dengan 3 (tiga) cara, yaitu atribusi, delegasi, dan mandat. Diskresi kepolisian dimaksudkan sebagai tindakan atau keputusan yang diambil oleh polisi berdasarkan syarat-syarat atau pertimbangan-pertimbangan yang dianggap paling tepat dan diyakini kebenarannya dan dipertanggungjawabkan berdasarkan hukum. Diskresi timbul setelah terjadi suatu pelanggaran pidana, namun polisi tidak melakukan tugas kewajibannya sebagai penegak hukum, artinya memproses berdasarkan legalitas hukum (KUHAP) namun justru menampilkan dirinya selaku pengayom, pembimbing dan pembina masyarakat, yaitu mengenyampingkan. Tindakan melanjutkan/memprosesnya itu berdasarkan pertimbangan konkret yang dihadapi di lapangan atau berdasarkan syarat-syarat yang dapat dipertanggungjawabkan. Sehingga tindakan polisi lebih cenderung memilih tindakan preventif dari pada represif.

Dalam instrumen internasional mengenai perlindungan hak-hak anak, tertuang dalam Resolusi PBB 44/25 tertanggal 20 November 1989 tentang Konvensi HakHak Anak (Convention on the Right of the Child). Konvensi ini lahir setelah melalui jalan yang panjang. ${ }^{2}$ Pasal 3 menyebutkan bahwa semua tindakan yang menyangkut anak yang dilakukan oleh lembaga-lembaga kesejahteraan sosial pemerintah atau swasta, lembaga peradilan, lembaga pemerintah atau badan legislatif, kepentingan terbaik anak akan merupakan pertimbangan utama. Adapun perlindungan anak khusus yang berkonflik dengan hukum, tertuang dalam Peraturan-peraturan Minimum Standar Perserikatan Bangsa-Bangsa Mengenai Administrasi Peradilan bagi Anak (United Nations Standart Minimum Rules for the Administration of Juvenile Justice (The Beijing Rules)), di antaranya dalam Butir 5 tentang tujuan peradilan anak. Rule 5. Aims of juvenile justice. 5.1. The juvenile justice system shall emphasize the well-being of the juvenile and shall ensure that eny reaction to juvenile offenders shall always be in proportion to the sircumstances of both the offenders and the offence.

${ }^{2}$ Made Sadhi Astuti, Hukum Pidana Anak dan Perlindungan Anak, Universitas Negeri Malang, 2003, hlm.13. 


\section{Rumusan Masalah}

Agar pengkajian lebih terfokus, maka permasalahan penelitian tersebut dirumuskan sebagai berikut: (1) Bagaimanakah penerapan vage normen sebagai sumber hukum diskresi oleh polisi penyidik anak? (2) Jenis-jenis tindak pidana apa yang dilakukan oleh anak yang dapat didiskresi?

\section{Tujuan Penelitian}

Adapun sebagai tujuan penelitian adalah, mengidentifikasi dan menganalisis tentang penerapan diskresi oleh polisi penyidik anak yang bersumber pada vage normen. Mengidentifikasi dan menganalisis jenis tindak pidana yang dilakukan oleh anak yang dapat didiskresi.

\section{Metode Penelitian}

Bertolak dari permasalahan penelitian dan dikaitkan dengan tujuan yang hendak dicapai maka penelitian ini adalah diskriptif-analitis yaitu mendiskripsikan perspektif untuk kebijakan kewenangan diskresi dalam rangka penerapan penyidikan. Penelitian ini metode pendekatannya disesuaikan dengan jenis penelitian yang dilakukan, dengan pendekatan hukum normatif (legal research) ${ }^{3}$ yang merupakan penelitian kepustakaan yaitu penelitian terhadap data sekunder, berupa bahan hukum. Dalam penelitian ini mencari data di Polresta Surabaya Timur, Polresta Malang, Polresta Kediri dan Polres Jember.

Sesuai dengan jenis penelitian, maka bahan hukum yang akan digunakan adalah bahan pustaka, yang dalam (ilmu) penelitian digolongkan sebagai data sekunder. Penggunaan data sekunder, terutama yang bersifat publik, yaitu data arsip, data resmi yang berupa bahan hukum pada instansi-instansi pemerintah, maupun data lain misalnya yurisprudensi Mahkamah Agung. ${ }^{4}$

Adapun pengumpulan data dalam penelitian lapangan (field research) dilakukan dengan cara studi dokumenter dan wawancara. ${ }^{5}$ Arsip dan dokumen yang ada pada

\footnotetext{
${ }^{3}$ Soerjono Soekanto dan Sri Mamudji, Penelitian Hukum Normatif, Suatu tinjanan Singkat, Rajawali, Jakarta, 1985, hlm. 28.

${ }^{4}$ Ibid., hlm. 29.

${ }^{5}$ Wawancara dengan Anggota Kepolisian bagian Polisi Penyidik Anak Resor Jember.
} 
sejumlah Kantor Resor Kepolisian yang dipakai sebagai sampel, yakni Surabaya, Malang, Kediri dan Jember.

Analisis yang digunakan dalam penelitian ini adalah analisis isi (content analisys) yaitu analisis yang dilakukan dengan cara membuat suatu pengkajian secara obyektif, sistematis dan melakukan suatu identifikasi khusus terhadap isi dokuman atau bahan hukum, dan isi wawancara yang diperoleh dari nara sumber. Sedangkan teknik berpikir analitiknya, menggunakan teknik berpikir deduktif, induktif dan komparatif.

\section{Tinjauan Pustaka}

Keberadaan hukum tidak dapat dilepaskan dari masyarakatnya, Cicero dalam ungkapan lamanya menyebutkan ubi societas ibi ius, di mana ada masyarakat di situ ada hukum. Ungkapan ini mengindikasikan keterkaitan antara masyarakat dengan hukum yang mengaturnya, masyarakat merupakan landasan sosiologis bagi terbentuknya hukum. Tidak berbeda dengan masyarakat Indonesia yang bercorak multi kultural, multi etnik, multi agama, multi ras dan multi golongan, dengan sesanti Bhineka Tunggal Ika secara de facto mencerminkan kemajemukan budaya bangsa dalam naungan Negara Kesatuan Republik Indonesia. ${ }^{6}$ Kemajemukan masyarakat Indonesia dengan segala atribut yang menyertainya sangat mempengaruhi tatanan kehidupan sosialnya, termasuk kehidupan hukum yang terpelihara dalam masyarakat.

Nilai-nilai kehidupan masyarakat akan sangat mempengaruhi dan mewarnai substansi hukum, maupun terhadap sistem hukum yang ada. Fakta bahwa keragaman masyarakat menunjukkan kebhinekaan hukum atau state law, secara de facto juga terdapat sistem hukum adat, hukum agama atau religius law, dan juga mekanisme regulasi sendiri atau dalam komunitas-komunitas masyarakat di daerah. ${ }^{7}$ Penyeragaman terhadap keanekaragaman nilai-nilai kehidupan masyarakat melalui satu tatanan dan takaran norma hukum merupakan sebuah ironi yang mengingkari fakta dan realitas kehidupan masyarakat yang majemuk. Setiap lingkungan masyarakat memiliki batasan atau tolok ukur masing-masing terhadap konsep norma yang membingkai perilaku kehidupan sosialnya.

\footnotetext{
${ }^{6}$ Nyoman Nurjaya, Reorientasi Pembangunan Hukum Negara Dalam Masyarakat Multi Kultural Perspektif Antropologi Hukum, Pidato Pengukuhan Jabatan Guru Besar pada Fakultas Hukum Universitas Brawijaya, Malang, 2007, hlm.1. ${ }^{7}$ Ibid., hlm. 23.
} 
Perumusan vage normen atau norma samar akan memberikan keleluasaan pengemban kewenangan untuk menyesuaikan berlakunya norma hukum positif dalam masyarakat, akan bersifat fleksibel dalam situasi dan kondisi dimana norma hukum positif tersebut berlaku. ${ }^{8}$ Setiap negara hukum, apa pun tipe yang dianutnya (rechtstaat, atau the rule of law) termasuk di Indonesia, membawa konsekuensi berlakunya prinsip, bahwa setiap tindakan tata usaha negara harus berlandaskan pada hukum yang berlaku atau hukum positif, "memerintah ada hukumnya". 9 Prinsip ini menghendaki bahwa setiap tindakan tata usaha negara harus bertumpu pada asas keabsahan hukum, dengan demikian setiap penggunaan wewenang pemerintahan harus dapat ditemukan atau ditentukan dasar hukumnya secara jelas dan pasti untuk mencegah tindakan sewenang-wenang yang dapat merugikan.

Dalam perkembangannya penggunaan hukum positif sebagai tumpuan asas wetmatigheid van bestuur sering ditemukan permasalahan, di antaranya banyak tindakan tata usaha negara yang tidak didasarkan pada peraturan perundangundangan, melainkan hanya berdasarkan instruksi, surat edaran, petunjuk atasan, perundang-undangan semu dan sebagainya. ${ }^{10}$ Mengenai hal ini van Wijk dan Konijnenbelt menyatakan, hal yang tidak mungkin dilaksanakan, bahwa untuk setiap tindakan tata usaha negara itu diharuskan adanya dasar legalitas secara absolut, karena hal ini tidak akan menghasilkan apa-apa. ${ }^{11}$

Di samping itu, penggunaan hukum positif yang berkaitan dengan vage normen juga dapat ditemukan hampir dalam setiap produk perundang-undangan dalam berbagai bentuk dan tingkatan. Vage normen dalam praktek dapat "melahirkan" diskresi oleh pejabat tata usaha negara berupa tindakan tata usaha negara yang tidak didasari norma hukum yang pasti. Dengan perkataan lain, vage normen sebagai sumber hukum dari diskresi. Tindakan yang demikian bersifat dilematis, sebab di satu sisi seakan-akan tindakan tersebut kurang sesuai dengan prinsip negara hukum, namun pada sisi lain tindakan tersebut harus dilakukan dalam rangka menyelenggarakan tugas-tugas kepentingan umum.

\footnotetext{
${ }^{8}$ SlametSuhartono, Vage Normen Sebagai Dasar Tindakan Hukum Tata Usaha Negara, Disertasi Program Doktor Ilmu Hukum Fakultas Hukum Universitas Brawijaya, Malang, 2009, hlm. 8.

9 Philipus M. Hadjon, Pemerintah Menurut Hukum, Kerjasama Indonesia-Belanda, Universitas Airlangga, Surabaya, 1991, hlm. 27.

${ }^{10}$ Indroharto, Usaha Memahami Undang-undang Nomor 5 Tabun 1986 Tentang Peradilan Tata Usaha Negara, Pustaka Sinar Emas, Jakarta, 2002, hlm. 105.

${ }^{11}$ Ibid., hlm. 106.
} 
Diskresi itu dapat menimbulkan tindakan penyalahgunaan wewenang, dan kesewenang-wenangan karena pejabat tata usaha negara dapat menggunakan penafsirannya dalam penerapan vage normen tersebut. Namun demikian harus diakui bahwa dalam negara hukum modern dengan mengingat sifat aktif dan luasnya urusan pemerintahan, vage normen dapat melahirkan keleluasaan dan keluwesan bagi pejabat tata usaha untuk melakukan tindakan-tindakannya sesuai dengan kebutuhan dan perkembangan yang terjadi. ${ }^{12}$

Dalam The Basic Dictionary of American English discretion, diskresi diartikan sebagai ability to choose wisely or to judge for ownself, artinya kemampuan untuk memilih secara bijaksana atau mempertimbangkan bagi diri sendiri. ${ }^{13}$ Rancangan UndangUndang Tentang Administrasi Pemerintahan menyebutkan bahwa, diskresi adalah kewenangan pejabat administrasi pemerintahan yang digunakan dalam mengambil keputusan untuk mengatasi masalah dengan memperhatikan batas-batas hukum yang berlaku, asas-asas umum pemerintahan yang baik dan norma-norma yang berkembang di masyarakat.

\section{Hasil dan Pembahasan}

\section{Kasus Anak yang Terlibat Tindak Pidana}

Di sini disajikan kasus-kasus yang berkaitan dengan tidak atau belum diterapkan diskresi kepolisian terhadap anak yang disangka sebagai pelaku tindak pidana.

1. Kasus tahun 2003 tentang anak STM yang terlibat tawuran. Danang usia 15 tahun anak STM Jakarta Barat, terlibat tawuran dengan siswa lain. Danang dengan tiga rekannya dibawa ke Kepolisian Sektor setempat di wilayah Kebayoran Baru. Siksaan pertama diterima Danang di kantor polisi ketika penyidik dan oknum polisi memukuli dan menendang mereka. Pukulan kembali mereka terima ketika masuk ke sel tahanan yang mayoritas diisi laki-laki dewasa. Siksaan kembali diterima Danang ketika ia dilimpahkan polsek ke Rumah Tahanan Negara Pondok Bambu. Di Blok C, ia dimasukkan ke sebuah sel berisi yang dihuni 25 (dua puluh lima) orang. Padahal ukuran kamar hanya 3 x 4 meter. Di sini siksaan malah lebih parah. Begitu masuk,

${ }^{12}$ Slamet Suhartono, Op. Cit., hlm.2.

${ }_{13}$ Alvina Treut Burrow, et.al, The Basic Dictionary of American Inglish, Renehart and Winston Inc, New York, 1966, hlm. 226. 
Danang bukan hanya dipukuli. Kepalanya dihajar batu bata. Tidak hanya kepala kamar yang memukuli tetapi juga anak-anak lain sesama tahanan. Mereka disuruh memukuli orang baru. Empat anak lain yang masuk bersama Danang berusia 14 hingga 17 tahun tak bisa menghindari siksaan. Pakaian mereka dilucuti, bukan hanya dipukuli, mereka juga harus "pasrah" saat kaki mereka ditetesi lelehan plastik yang dibakar. Jeritan kesakitan pun menggema di selusuh Blok C. Siksaan dilanjutkan keesokan harinya. Keempat anak ini disuruh bergantian berdiri membelakangi dinding dan tangan direntangkan. Lalu satu demi satu secara bergantian, anak-anak di sel itu secara bergantian melemparkan batu baterai, entah diperoleh dari mana ke arah anak yang harus mengalami siksaan itu tetesan darah dan jeritan kesakitan tidak menghalangi berlanjutnya siksaan. ${ }^{14}$

2. Kasus anak tahun 2007 tentang JB yang memperkosa teman bermain.

JB (12 tahun) yang memperkosa teman bermain, Cipluk (nama samaran), 9 th. kemarin menerima vonis hukuman dari Pengadilan Negeri (PN) Situbondo, bocah asal Bungatan itu divonis penjara 3 (tiga) tahun dan denda Rp 60.000.000,00, jika tak mampu membayar denda, anak itu bisa menggantinya dengan menjalani hukuman kurungan pengganti denda selama 6 (enam) bulan. Hingga kini JB masih berada di Rumah Tahanan (Rutan) Situbondo. Vonis yang dijatuhkan oleh hakim Ujianti itu lebih ringan dibandingkan dengan tuntutan jaksa penuntut umum (JPU) Suryani yang menuntutnya dengan hukuman 54 bulan atau 4,6 tahun penjara. Akibatnya JPU menyatakan banding. JB yang tampil ke persidangan tanpa kuasa hukum tidak memberikan komentar terhadap putusan hakim itu. Proses persidangan murid kelas VISD itu digelar sejak 22 Maret 2007 itu dilakukan tertutup. Hanya pembacaan putusan hakim sidang dinyatakan terbuka untuk umum. Karena ini masalah asusila, apalagi korban dan pelakunya masih anak di bawah umur. ${ }^{15}$

3. Kasus tahun 2009 tentang 10 (sepuluh) anak yang berjudi koin di Bandara Soekarno-Hatta.

Sarifudin, Musa, Takim, Abdul Rohman, Abdul Rohim, Bahrudin, Rohsidik, Irvan Ardiansah, Abdul Dofar, dan Rojali adalah 10 (sepuluh) anak di kampung Rawa Rengas kecamatan Kosambi, Tangerang yang divonis bebas bersyarat dan dikembalikan kepada orang tuanya masing-masing oleh Majelis hakim Pengadilan Tangerang 27 Juli 2009 karena terbukti berjudi koin di Bandara Soekarno-Hatta.

\footnotetext{
${ }^{14}$ Kompas, tanggal 28 Oktober 2003, hlm. 10.

${ }^{15}$ Jawa Pos, tanggal 17 April 2007, hlm. 33 dan hlm.39.
} 
Sebelum itu, kuasa hukum Christine Tambunan menilai judi yang dilakukan anak itu hanya mencari kesenangan sebab uang yang dipakai taruhan hanya Rp. 1.000,00 (Seribu Rupiah) dan bagi yang menang dipakai untuk makan bersama dan mereka pulang tidak membawa uang. Jadi di mana letak judinya? Persidangan itu menuai protes dari Komisi Perlindungan Anak Indonesia dengan cara mengajukan keberatan ke Kejaksaan Negeri Tangerang, dan berencana mengajukan jaksa penuntut ke Kejaksaan Agung. Aris Merdeka Sirait Sekjen Komnas Perlindungan Anak menjelaskan bahwa jaksa tidak dapat membuktikan baik formal maupun non formal tindak kriminal perjudian yang dilakukan anak-anakitu. Aris Merdeka Sirait selanjutnya menyatakan bahwa proses hukum yang dijalani mereka mulai dari penangkapan, penahanan dan pengadilan tidak memiliki perspektif perlindungan anak. Seharusnya aparat hukum yang menangani kasus tersebut memiliki sensitivitas, simpati dan empati terhadap perlindungan anak. Sikap Kejaksaan Negeri Tangerang tidak layak bagi anak di bawah umur dengan memberlakukan KUHP Pasal 303, ayat (1) ke 2 sebagai tuntutan primer dan Pasal 303 bis ayat (1) ke 2 sebagai tuntutan subsider tentang perjudian. Komisaris KPAI Magdalena Sitorus menuding ada unsur pembohongan publik oleh majelis hakim yang diketuai oleh Retno Pudianingtyas yang membacakan rekomendasi dari KPAI yang menyetujuai putusan bersalah dan merekomendasi KUHP Pasal 303 untuk dijadikan acuan putusan. Padahal KPAI tidak pernah mengeluarkan rekomendasi, namun justru mendesak agar anak-anak tersebut dibebaskan tanpa syarat. ${ }^{16}$ Kasus di atas menunjukkan bahwa penyidik tidak memanfaatkan kewenangan diskresinya dalam rangka mewujudkan sensitivitas kesejahteraan anak.

Ditinjau dari aspek yuridis tindakan penyidik bertentangan dengan ketentuan Undang-undang No. 23/2002 tentang Perlindungan Anak Pasal 16 jo Undang-undang No. 3/1997 tentang Pengadilan Anak Pasal 41 dan Pasal 42 jo Undang-undang No. 4/1979 tentang Kesejahteraan Anak Pasal 6, dan bertentangan dengan asas praduga tak bersalah.

Selain kasus-kasus di atas juga dapat dipaparkan lebih lanjut pada tabel 1, tabel 2, tabel 3 dan tabel 4 disertai wawancara dari nara sumber dari masing-masing lokasi.

${ }^{16}$ Jawa Pos, 23 Juli 2009, hlm. 11, dan 27 Juli, 2009, hlm. 1. 


\title{
Kasus Anak yang Terlibat Tindak Pidana di Polres Jember
}

\author{
Tabel 1
}

Kasus Anak yang Terlibat Tindak Pidana

Periode Tahun 2005-2007 di Polres Jember

\begin{tabular}{|c|c|c|c|c|c|c|c|c|}
\hline \multirow{2}{*}{ No } & \multirow{2}{*}{ Jenis Kasus } & \multicolumn{3}{|c|}{ Tahun } & \multirow{2}{*}{ Ditahan } & \multirow{2}{*}{\begin{tabular}{|c|} 
Tidak \\
ditahan
\end{tabular}} & \multirow{2}{*}{ Jumlah } & \multirow{2}{*}{$\%$} \\
\hline & & 2005 & 2006 & 2007 & & & & \\
\hline 1. & Perkosaan & 2 & 1 & 1 & 4 & - & 4 & 8,16 \\
\hline 2. & Pencabulan & 1 & 2 & 2 & 5 & - & 5 & 10,20 \\
\hline 3. & Penganiayaan & - & - & - & - & - & - & - \\
\hline 4. & Membawa Lari Wanita & - & - & - & - & - & - & - \\
\hline 5. & Zina & - & - & - & - & - & - & - \\
\hline 6. & Pembunuhan & - & - & 1 & 11 & - & 11 & 2,04 \\
\hline 7. & Pencurian & 1 & 1 & 6 & 9 & - & 9 & 38,76 \\
\hline 8. & Perjudian & 9 & 1 & - & 10 & - & 10 & 20,4 \\
\hline 9. & Penipuan & 1 & 2 & 1 & 4 & - & 4 & 8,16 \\
\hline 10. & Mencuri Hasil Hutan & 2 & 1 & - & 3 & - & 3 & 6,12 \\
\hline 11. & Membawa Sajam & 1 & 2 & - & 3 & - & 3 & 6,12 \\
\hline & Jumlah & 17 & 21 & 11 & 49 & - & 49 & \\
\hline & $\%$ & 34,68 & 42,84 & 22,44 & & & & 100 \\
\hline
\end{tabular}

Sumber : Bahan diolah Studi dokumen di Kepolisian Resor Jember tanggal 9 Januari 2008.

Berdasarkan data pada tabel 1 tampak, bahwa jumlah kasus anak yang terlibat tindak pidana dalam berbagai kasus, yakni; perkosaan, pencabulan, pembunuhan, pencurian, perjudian, penipuan, pencurian hasil hutan dan membawa senjata tajam selama 3 (tiga) tahun dari tahun 2005 sampai dengan tahun 2007, adalah sebagai berikut: Tahun 2005 ada 17 (tujuh belas) kasus atau 34,68 \%, tahun 2006 ada 21 (dua puluh satu) kasus atau 42,84\%, tahun 2007 ada 11 (sebelas) kasus atau 22,44\%. Di sini tampak bahwa jumlah kasus anak yang terlibat tindak pidana selama 3 (tiga) tahun besifat fluktuatif.

Hasil wawancara dengan nara sumber AIPTU Tri Muji Wilujeng, dari 49 (empat puluh sembilan) kasus dapat dibedakan menjadi 2 (dua) kelompok, yakni kasus yang tidak dapat didiskresi dan kasus yang memungkinkan dapat didiskresi. Kasus yang tidak dapat didiskresi adalah kasus perkosaan, pencabulan dan pembunuhan, sedangkan kasus yang memungkinkan dapat didiskresi adalah kasus pencurian, perjudian, penipuan, mencuri hasil hutan dan membawa sajam. Jumlah kasus yang 
tidak dapat didiskresi ada 10 (sepuluh) kasus atau 20,36\% (dua puluh koma tiga puluh enam persen), sedangkan kasus yang memungkinkan dapat didiskresi ada 39 (tiga puluh sembilan) kasus atau 79,64\% (tiga puluh sembilan koma enam puluh empat persen). Dari 49 (empat puluh sembilan) kasus itu semua ditahan dan semua diproses secara hukum untuk selanjutnya diajukan ke Penuntut Umum.

Hal demikian karena kasus yang pelakunya ditahan di Polres Jember berasal dari Polsek-Polsek yang ada pada setiap kecamatan di Jember. Berkaitan dengan itu maka semua pelaku yang ditahan di Polres Jember berumur 14 tahun sampai 18 tahun.

Adapun kasus yang paling banyak adalah kasus pencurian, ada 19 (sembilan belas) kasus atau 38,76\% ( tiga puluh delapan koma tujuh puluh enam persen) berupa pencurian ringan, misalnya mencuri telpon genggam, barang dagangan di toko dan sebagainya.

\section{Kasus Anak yang Terlibat Tindak Pidana di Polresta Kediri}

\section{Tabel 2}

Kasus Anak yang Terlibat Tindak Pidana

Periode Tahun 2005-2007 di Polresta Kediri

\begin{tabular}{|c|c|c|c|c|c|c|c|c|}
\hline \multirow{2}{*}{$\mathrm{No}$} & \multirow{2}{*}{ Jenis Kasus } & \multicolumn{3}{|c|}{ Tahun } & \multirow{2}{*}{ Ditahan } & \multirow{2}{*}{$\begin{array}{c}\text { Tidak } \\
\text { ditahan }\end{array}$} & \multirow{2}{*}{ Jumlah } & \multirow{2}{*}{$\%$} \\
\hline & & 2005 & 2006 & 2007 & & & & \\
\hline 1. & Perkosaan & 1 & 3 & - & 4 & - & 4 & 12,12 \\
\hline 2. & Pencabulan & 1 & 1 & - & 2 & - & 2 & 6,06 \\
\hline 3. & Penganiayaan & - & - & 2 & 2 & - & 2 & 6,06 \\
\hline 4. & Membawa Lari Wanita & - & - & - & - & - & - & - \\
\hline 5. & Zina & - & - & - & - & - & - & - \\
\hline 6. & Pembunuhan & - & - & - & - & - & - & - \\
\hline 7. & Pencurian & 1 & 1 & - & 2 & - & 2 & 6,06 \\
\hline 8. & Perjudian & 5 & 7 & 3 & 15 & - & 15 & 45,45 \\
\hline 9. & Penipuan & 1 & 3 & - & 4 & - & 4 & 12,12 \\
\hline 10. & Mencuri Hasil Hutan & - & - & - & - & - & - & - \\
\hline 11. & Membawa Sajam & 1 & 1 & 2 & 4 & - & 4 & 12,12 \\
\hline & Jumlah & 10 & 16 & 7 & 33 & - & 33 & \\
\hline & $\%$ & 30,3 & 48,48 & 21,21 & & & & 100 \\
\hline
\end{tabular}

Sumber : Bahan diolah Studi dokumen di Kepolisian Resor Kota Kediri tanggal 9 Oktober 2008. 
Berdasarkan data pada tabel 2 tampak bahwa jumlah kasus anak yang terlibat tindak pidana dalam berbagai kasus, yakni; perkosaan, pencabulan, penganiayaan, pencurian, perjudian, penipuan, dan membawa senjata tajam selama 3 (tiga) tahun dari tahun 2005 sampai dengan tahun 2007, adalah sebagai berikut: Tahun 2005 ada 10 (sepuluh) kasus atau 30,3 \% (tiga pulug koma tiga). Tahun 2006 ada 16 (enam belas) kasus atau 48,48\% (empat puluh koma empat puluh delapan persen). Tahun 2007 ada 7 (tujuh) kasus atau 21,21\% (dua puluh satu koma dua puluh satu persen). Tampak bahwa jumlah kasus anak yang terlibat tindak pidana selama 3 (tiga) tahun besifat fluktuatif.

Kasus yang ada di Polresta Kediri tidak jauh berbeda dengan kasus di Polres Jember, hal ini terungkap dari hasil wawancara dengan AIPTU Ida. Perbedaannya adalah di Polres Jember anak tersangkut 8 (delapan) jenis kasus yakni perkosaan, pencabulan, pembunuhan, pencurian, perjudian, penipuan, mencuri hasil hutan dan membawa sajam, sedangkan di Polresta Kediri anak tersangkut 7 (tujuh) jenis kasus yakni; perkosaan, pencabulan, penganiayaan, pencurian, perjudian, penipuan dan membawa sajam. Jumlah kasus yang tidak dapat didiskresi ada 8 kasus atau 24,24\% (dua puluh empat koma dua puluh empat persen), sedangkan kasus-kasus yang memungkinkan dapat didiskresi ada 25 (dua puluh lima) kasus atau 75,76\% (tujuh puluh lima koma tujuh puluh enam persen), yakni kasus pencurian, perjudian, penipuan dan membawa sajam. 


\section{Kasus Anak yang Terlibat Tindak Pidana di Polresta Surabaya Timur}

Tabel 3

Kasus Anak yang Terlibat Tindak Pidana

Periode Tahun 2005-2007 di Polresta Surabaya Timur

\begin{tabular}{|c|c|c|c|c|c|c|c|c|}
\hline \multirow{2}{*}{$\mathrm{No}$} & \multirow{2}{*}{ Jenis Kasus } & \multicolumn{3}{|c|}{ Tahun } & \multirow{2}{*}{ Ditahan } & \multirow{2}{*}{$\begin{array}{l}\text { Tidak } \\
\text { ditahan }\end{array}$} & \multirow{2}{*}{ Jumlah } & \multirow{2}{*}{$\%$} \\
\hline & & 2005 & 2006 & 2007 & & & & \\
\hline 1. & Perkosaan & - & - & - & - & - & - & - \\
\hline 2. & Pencabulan & 1 & - & - & 1 & - & 1 & 1,72 \\
\hline 3. & Penganiayaan & 2 & 1 & 3 & 6 & - & 6 & 10,34 \\
\hline 4. & Membawa Lari Wanita & - & - & - & - & - & - & - \\
\hline 5. & Zina & - & - & - & - & - & - & - \\
\hline 6. & Pembunuhan & - & - & - & - & - & - & 50 \\
\hline 7. & Pencurian & 6 & 11 & 12 & 29 & - & 29 & 6,9 \\
\hline 8. & Perjudian & - & - & 4 & 4 & - & 4 & 13,8 \\
\hline 9. & Penipuan & 3 & 4 & 1 & 8 & - & 8 & - \\
\hline 10. & Mencuri Hasil Hutan & - & - & - & - & - & - & 17,24 \\
\hline 11. & Membawa Sajam & 2 & 3 & 5 & 10 & - & 10 & \\
\hline & Jumlah & 14 & 19 & 25 & 58 & - & 58 & \\
\hline & $\%$ & 24,13 & 32,75 & 43,1 & & & & 100 \\
\hline
\end{tabular}

Sumber : Bahan diolah Studi dokumen di Kepolisian Resor Kota Surabaya Timur tanggal 20 Oktober 2008

Berdasarkan data pada tabel 3 tampak, bahwa jumlah kasus anak yang terlibat tindak pidana dalam berbagai kasus, yakni; perkosaan, pencabulan, penganiayaan, pencurian, perjudian, penipuan, dan membawa senjata tajam selama 3 (tiga) tahun dari tahun 2005 sampai dengan tahun 2007, adalah sebagai berikut: Tahun 2005 ada 14 (empat belas) kasus atau 24,13\% (dua puluh empat koma tiga belas persen). Tahun 2006 ada 19 (sembilan belas) kasus atau 32,75\% (tiga puluh dua koma tujuh puluh lima persen). Tahun 2007 ada 25 (dua puluh lima) kasus, 43,1\% (empat puluh tiga koma satu persen).

Tampak bahwa jumlah kasus anak yang terlibat tindak pidana selama 3 tahun semakin meningkat. Kasus di Polresta Surabaya Timur jauh berbeda dengan kasuskasus di Polres Jember dan Polresta Kediri sebab Polresta Surabaya Timur wilayah hukumnya merupakan (se)bagian dari kota metropolitan Surabaya sebagai ibu kota Provinsi Jawa Timur yang amat padat penduduknya. Kondisi demikian berakibat langsung terhadap peningkatan tindak kejahatan baik jumlah maupun frekuensinya 
terutama kasus pencurian, termasuk tindak kejahatan yang pelakunya anak. Kasuskasus tersebut terungkap juga dari hasil wawancara dengan Hartoyo, S.IK. Jenis kasusnya lebih sedikit bila dibandingkan dengan kassus di Polres Jember dan Polresta Kediri. Perbedaannya adalah di Polres Jember anak tersangkut 8 (delapan) jenis kasus yakni perkosaan, pencabulan, pembunuhan, pencurian, perjudian, penipuan, mencuri hasil hutan, dan membawa sajam. Di Polresta Kediri anak tersangkut 7 (tujuh) jenis kasus yakni; perkosaan, pencabulan, penganiayaan, pencurian, perjudian, penipuan dan membawa sajam. Di Polresta Surabaya Timur anak tersangkut 6 (enam) jenis kasus yakni pencabulan, penganiayaan, pencurian, perjudian, penipuan dan membawa senjata tajan. Jumlah kasus yang tidak dapat didiskresi ada 1 (satu) kasus yaitu kasus pencabulan atau 1,724\% ( satu koma tujuh ratus dua puluh empat persen), sedangkan kasus yang memungkinkan dapat didiskresi ada 57 (lima puluh tujuh) kasus atau 98,276\% (sembilan puluh delapan koma dua ratus tujuh puluh enam persen) , yakni kasus penganiayaan, pencurian, perjudian, penipuan dan membawa sajam.

\section{Kasus Anak yang Terlibat Tindak Pidana di Polresta Malang}

\section{Tabel 4}

Kasus Anak yang Terlibat Tindak Pidana

Periode Tahun 2005-2007 di Polresta Malang

\begin{tabular}{|c|c|c|c|c|c|c|c|c|}
\hline \multirow{2}{*}{ No } & \multirow{2}{*}{ Jenis Kasus } & \multicolumn{3}{|c|}{ Tahun } & \multirow{2}{*}{ Ditahan } & \multirow{2}{*}{\begin{tabular}{|c|} 
Tidak \\
ditahan
\end{tabular}} & \multirow{2}{*}{ Jumlah } & \multirow{2}{*}{$\%$} \\
\hline & & 2005 & 2006 & 2007 & & & & \\
\hline 1. & Perkosaan & 1 & 3 & - & 4 & - & 4 & 12,12 \\
\hline 2. & Pencabulan & 1 & 1 & - & 2 & - & 2 & 6,06 \\
\hline 3. & Penganiayaan & - & - & 2 & 2 & - & 2 & 6,06 \\
\hline 4. & Membawa Lari Wanita & - & - & - & - & - & - & - \\
\hline 5. & Zina & - & - & - & - & - & - & - \\
\hline 6. & Pembunuhan & - & - & - & - & - & - & - \\
\hline 7. & Pencurian & 1 & 1 & - & 2 & - & 2 & 6,06 \\
\hline 8. & Perjudian & 5 & 7 & 3 & 15 & - & 15 & 45,45 \\
\hline 9. & Penipuan & 1 & 3 & - & 4 & - & 4 & 12,12 \\
\hline 10. & Mencuri Hasil Hutan & - & - & - & - & - & - & - \\
\hline 11. & Membawa Sajam & 1 & 1 & 2 & 4 & - & 4 & 12,12 \\
\hline & Jumlah & 10 & 16 & 7 & 33 & - & 33 & \\
\hline & $\%$ & 30,3 & 48,48 & 21,21 & & & & 100 \\
\hline
\end{tabular}

Sumber : Bahan diolah dari studi dokumen di Kepolisian Resor Kota Malang tanggal 1 Nopember 2008. 
Berdasarkan data pada tabel 4 tampak, bahwa jumlah kasus anak yang terlibat tindak pidana dalam berbagai kasus, yakni; perkosaan, pencabulan, penganiayaan, pencurian, perjudian, penipuan dan membawa senjata tajam selama 3 (tiga) tahun dari tahun 2005 sampai dengan tahun 2007, adalah sebagai berikut; Tahun 2005 ada 19 (sembilan belas) kasus atau 35,22\% (tiga puluh lima koma dua puluh dua persen), tahun 2006 ada 18 (delapan belas) kasus atau 33,36\% (tiga puluh tiga koma tiga puluh enam), tahun 2007 ada 17 ( tujuh belas ) kasus atau 31,51\% (tiga puluh satu koma lima puluh satu persen). Tampak bahwa jumlah kasus anak yang terlibat tindak pidana selama 3 (tiga) tahun semakin berkurang frekuensinya. Hasil wawancara dengan nara sumber Heru Prasetyo, S.IK., dari 54 (lima puluh empat) kasus dapat dibedakan menjadi 2 (dua) kelompok, yakni kasus-kasus yang tidak dapat didiskresi dan kasus-kasus yang memungkinkan dapat didiskresi. Kasus-kasus yang tidak dapat didiskresi adalah kasus perkosaan, pencabulan dan pembunuhan, sedangkan kasus-kasus yang memungkinkan dapat didiskresi adalah kasus-kasus pencurian, perjudian, penipuan dan membawa sajam. Jumlah kasus yang tidak dapat didiskresi ada 9 (sembilan) kasus atau 16,65\% (enam belas koma enam puluh lima persen), sedangkan kasus yang memungkinkan dapat didiskresi ada 45 (empat puluh lima) kasus atau 83,35\% (delapan puluh tiga koma tiga puluh lima persen). Dari 54 kasus itu semua ditahan dan semua diproses secara hukum untuk selanjutnya diajukan ke Penuntut Umum.

Hal demikian karena kasus yang pelakunya ditahan di Polresta Malang berasal dari Polsekta-Polsekta yang ada pada setiap kecamatan di Malang. Berkaitan dengan itu maka semua pelaku yang ditahan di Polresta Malang berumur 14 (empat belas) tahun sampai 18 (delapan belas) tahun. Kasus yang paling banyak adalah kasus pencurian, ada 25 (dua puluh lima) kasus atau 46,3\% (empat puluh enam koma tiga persen) berupa pencurian ringan, misalnya mencuri telpon genggam, barang dagangan di toko dan sebagainya.

Materi yang terkait dengan diskresi yang ada di lapangan baik dalam dokumen maupun yang dapat digali dari beberapa nara sumber dapat disarikan bahwa kasuskasus tindak pidana anak yang memungkinkan dapat didiskresi adalah penganiayaan ringan, pencurian ringan, perjudian, penipuan dan membawa senjata tajam.

Kenyataannya bahwa kewenangan diskresi tidak diterapkan pada kasus tindak pidana yang dilakukan oleh anak tersebut di atas, menunjukkan belum atau tidak sesuainya antara peraturan perundang-undangan yang berlaku dengan praktek yang 
ada di lapangan. Hal demikian karena ketidakjelasan atau kurang rincinya peraturan tentang diskresi khususnya yang terkait dengan anak nakal bila dibandingkan dengan peraturan tentang diskresi yang ada dalam The Beijing Rules.

Ketentuan diskresi yang diatur dalam instrumen internasional dalam The Beijing Rules pada Rules 6.1, 11.1, 12.1, 13.1,

Rule 6.1. In view of the varying special needs of juveniles as well as the variety of measures available, appropriate scope for discretion shall be allowed at all stages of proceedings and at the different levels of juvenile justice administration, prosecution, adjudication and the follow-up disposition.

Rule 11.1. Consideration shall be given wherever appopiate, to dealing with juvenile offenders without resorting to formal trial by the competent authority, reffered to in rule 14.1 below.

Rule 12.1. In order to best fulfil teir function, police officers who frequently or exclusively deal with juveniles or who are primarily engaged in the prevention of juvenile crime shall be specialy instructed and trained. In large cities, special police units should be established for the purpose.

Rule 13.1. Detention pending trial shall be used only as measure of last resort and for the shortest possible of time.

Demikian juga tentang contoh kasus di Amerika tentang bagaimana polisi menangani kenakalan anak dengan menggunakan kewenangan diskresi.

Minor Possession of Alcohol - Pretrial Probation - Discretion Program. The 16-yearold female juvenile was not supposed to be home but climbed through a rear window to access her mother's house. A party subsequently ensued in the absence of her mother who was in California. Police responded to a reported neighborhood disturbance and saw a large group of youths running from the house, some loudly yelling, "Run, the cops are here! Police found large quantities of open beer cans throughout the entire house and in the back yard. The female juvenile contradicted herself and was purposely vague in explaining the detail of the party and alcohol. Mr. Arnel, a policeman sought to prevent any criminal entry upon to the female jouvenile previously unbremished record and wisely negotiation. Mr. Arnel secired placement in a discretion program with pretrial probation for a mere 4 months and only 10 hours. She successfully and easily completed theprogram. ${ }^{17}$

${ }^{17}$ http:/ /www.arnellaw.com/CM/Custom/TOCJuvenileCrimeCaseSummaries.asp 
Dalam tahap penyidikan anak, juga didukung oleh instrumen internasional yaitu “The Beijing Rules" yang dapat dipakai sebagai pedoman, menegaskan bahwa diskresi oleh penyidik diatur dalam Rule 6. (Scope of discretion)

Rule 6.3. Those who exersice discretion shall be specially qualified or trained to exersice it judiciously and in accordance with their function and mandates.

Demikian juga pada Penjelasan Umum dan Pasal 18 ayat (1) beserta penjelasannya pada Undang-Undang No. 2 Tahun 2002 tentang Kepolisian Negara, masih ada kekurangan, antara lain tentang syarat-syarat yang harus dimiliki oleh pejabat kepolisian agar dapat melaksanakan fungsinya sebaik mungkin, maka polisi harus dilatih secara khusus, sesuai dengan The Beijing Rule 12.1. Di samping itu dalam Undang-undang Kepolisian Negara belum diatur tentang jenis-jenis tindak pidana apa saja yang dapat didiskresi.

Sebagai contoh ketentuan tentang diskresi dalam sistem hukum di negara Jepang. Undang-undang Pengadilan Anak Jepang tahun 1948 yang sudah disempurnakan dalam Pasal 24 mengatur 3 (tiga) tindakan perlindungan anak di bidang pendidikan, (a) penempatan anak di bawah pengawasan probation; (b) perintah memasukkan anak ke dalam asrama pelatihan atau asrama pendidikan anak; (c) perintah memasukkan anak ke dalam sekolah pelatihan anak.

Polisi dalam berbagai aktivitas pencegahan delinkuensi lewat jaringan kelembagaan anak dan ditugasi menangani anak pre-delinquent atau pre-offence, anak yang melakukan perbuatan tak terpuji seperti merokok, kluyuran setelah tengah malam. Apabila polisi menemukan anak berperilaku demikian, maka segera ditangani dan diberi peringatan atau pengarahan. Menurut hukum anak, polisi mengajukan kasus tersebut ke pengadilan keluarga atau pusat bimbingan anak, apabila dinilai oleh petugas lembaga itu, anak memerlukan tindakan perlindungan maka pimpinan lembaga itu akan mengajukan kasus itu langsung atau melalui penuntut umum kepada pengadilan keluarga. Oleh karena penuntut umum tidak berwenang melakukan diskresi, maka baik polisi maupun penuntut umum harus segera mengajukan kasus itu pada pengadilan keluarga, bila perlu dilampiri pendapat polisi atau penuntut umum tentang kasus bersangkutan. Pendapat polisi atau penuntut umum itu dilampirkan karena mereka tidak berhak hadir dalam sidang pemeriksaan pengadilan keluarga. Disposisi ajudikasi hakim pengadilan keluarga biasanya tidak berbeda jauh dengan pandangan polisi atau penuntut umum yang sama-sama berangkat dari satu prinsip demi kepentingan umum. 
Pengadilan anak mempunyai yurisdiksi 3 (tiga) jenis anak, (a) anak pelaku delinkuen yang berusia antara 14 - 19 tahun; (b) anak pelaku pelanggaran hukum berusia di bawah 14 tahun; dan (c) anak pelaku kejahatan yang berusia di bawah 20 tahun yang terbukti rentan berperilaku jahat. Pembuktiannya dilakukan secara paternalisme. Prosedur peradilan anak lebih bersifat protektif daripada yang lazimnya diperuntukkan bagi orang dewasa. Pidana yang akan dijatuhkan pada anak pun dapat dikurangi jangka waktunya.

Kasus-kasus tersebut di atas yang berupa perbandingan penerapan diskresi di negara lain yaitu Amerika Serikat dan Jepang dibandingkan dengan di negara kita menunjukkan bahwa belum diterapkannya Undang-Undang Republik Indonesia No. 2 Tahun 2002 tentang Kepolisian Negara, mengenai kewenangan diskresi. Dalam Penjelasan Umum pejabat kepolisian memiliki kewenangan diskresi yaitu kewenangan untuk bertindak demi kepentingan umum berdasarkan penilaian sendiri. Kewenangan diskresi tersebut penjabaran dalam pasal-pasalnya masih belum memadai sebab hanya dimuat dalam Pasal 16 dan ketentuan ini berlaku umum baik untuk orang dewasa maupun untuk anak.

Pasal 16 ayat (1) huruf 1. Undang-undang Kepolisian: Dalam rangka menjalankan tugas sebagaimana dimaksud dalam Pasal 13 dan Pasal 14 di bidang proses pidana, Kepolisian Negara Republik Indonesia berwenang untuk: 1. mengadakan tindakan lain menurut hukum yang bertanggung jawab.

Pasal 16 ayat (2). Undang-undang Kepolisian: Tindakan lain sebagaimana dimaksud dalam ayat (1) huruf l adalah tindakan penyelidikan dan penyidikan yang dilaksanakan jika memenuhi syarat sebagai berikut: (a) tidak bertentangan dengan suatu aturan hukum, (b) selaras dengan kewajiban hukum yang mengharuskan tindakan tersebut dilakukan; (c) harus patut, masuk akal dan termasuk dalam lingkungan jabatannya; (d) pertimbangan yang layak berdasarkan keadaan yang memaksa; dan (e) menghormati hak asasi manusia.

Pasal 18 ayat (1) yang masih berkaitan dengan kewenangan diskresi menyebutkan bahwa: Untuk kepentingan umum pejabat Kepolisian Negara Republik Indonesia dalam melaksanakan tugas dan wewenangnya dapat bertindak menurut penilaiannya sendiri.

Penjelasan Pasal 18 ayat (1) menjelaskan bahwa yang dimaksud dengan "bertindak menurut penilaiannya sendiri" adalah suatu tindakan yang dapat dilakukan oleh anggota Kepolisian Republik Indonesia yang dalam bertindak harus 
mempertimbangkan manfaat serta risiko dari tindakannya dan betul-betul untuk kepentingan umum.

Namun dalam kenyataannya ketentuan Pasal 16 dan Pasal 18 Undang-undang Kepolisian Negara yang mengatur kewenangan diskresi yang berlaku secara umum baik untuk orang dewasa maupun untuk anak belum pernah dimanfaatkan atau diterapkan.

Adapun mengenai jenis-jenis tindak pidana anak yang memungkinkan untuk didiskresi adalah sebagai berikut; tawuran, pencurian ringan, permainan uang tanpa unsur perjudian; perusakan barang secara terbuka atas barang pribadi secara terbuka (vandalisme); pembakaran yang membahayakan barang; pencurian tanpa membobol rumah; penggelapan barang; percobaan melakukan tindak pidana ringan; penadahan; pembinasaan atau perusakan barang, termasuk pencorengan saran publik; merusak barang; berandalan; pelanggaran lalu lintas; menyulut petasan yang membahayakan lingkungan umum; membolos sekolah; melarikan diri dari rumah; tersangkut kasus obat-obatan terlarang; tersangkut atau pelaku kecelakaan lalu lintas. Keluyuran setelah tengah malam; pelanggaran yang tidak menyangkut kepentingan umum dan merokok.

\section{Penutup}

Berdasarkan uraian di atas dapat disimpulkan bahwa, kewenangan diskresi pada polisi yang bersumber pada vage normen secara umum belum atau tidak diterapkan. Karena belum jelas peraturan perundang-undangannya, misalnya; jenis-jenis tindak pidana apa yang memungkinkan untuk didiskresi sebab tidak semua jenis tindak pidana dapat didiskresi: perumusan persyaratan apa saja atas diri anak agar penuntutan pidana dapat dicegah. Polisi dalam bertindak harus mempertimbangkan manfaat serta risiko dari tindakannya dan betul-betul demi kepentingan umum. Pengertian “demi kepentingnan umum” juga harus diterangkan lebih lanjut agar tidak disalahgunakan polisi sebagai penyidik tunggal, sebab dapat juga berlindung “demi kepentingan umum" namun malah menyalahgunakan kewenangannya. Ketidakjelasan peraturan tentang diskresi dalam Undang-Undang No. 2 Tahun 2002 tentang Kepolisian Negara Republik Indonesia dibandingkan dengan ketentuan The Beijing Rules, tentang diskresi maka kewenangan diskresi polisi penyidik anak perlu diteliti dan disempurnakan. 
Polisi penyidik anak harus memperhatikan jiwa Undang-undang Pengadilan anak, Undang-undang Perlindungan Anak dan Undang-undang Kesejahteraan Anak yang intinya adalah "kepentingan terbaik bagi anak adalah prioritas utama”. Polisi penyidik anak harus memperhatikan instrument internasional terutama The Beijing Rules yang menghendaki bahwa kewenangan diskresi yang ada atau melekat pada polisi untuk diterapkan demi masa depan anak.

\section{Daftar Pustaka}

Aaron, Thomas J., The Control of Police Discretion, Springfield, Charles C, 1960.

Burrow, Alvina Treut, dkk., The Basic Dictionary of American Inglish, Renehart and Winston Inc, New York, 1966.

Faal, M., Penyaringan Perkara Pidana Oleh Polisi (Diskresi Kepolisian), Pradnya Paramita, Jakarta, 1991.

Garner, Bryan A., Black's Law Dictionary, By West Goup, St. Paul MIN, 1999.

Hadisuprapto, Paulus, Pemberian Malu Reintegratif Sebagai Sarana Nonpenal Penanggulangan Perilaku Delinkuensi Anak (Studi Kasus di Semarang dan Surakarta), Disertasi Program Doktor Universitas Diponegoro Semarang, 2002.

Indroharto, Usaha Memahami Undang-undang Nomor 5 Tahun 1986 Tentang Peradilan Tata Usaha Negara, Pustaka Sinar Emas, Jakarta, 2002.

Kementerian Pendayagunaan Aparatur Negara R.I.

Krisnawati, Emilia, Aspek Hukum Perlindungan Anak, C.V. Utomo, Bandung, 2005.

M. Hadjon, Philipus, Pemerintah Menurut Hukum, Kerja sama Indonesia-Belanda, Universitas Airlangga, Surabaya, 1991.

Nawawi Arief, Barda, Perbandingan Hukum Pidana, Rajawali Pers, Jakarta, 2002.

Nurjaya, Nyoman, Reorientasi Pembangunan Hukum Negara Dalam Masyarakat Multi Kultural Perspektif Antropologi Hukum, Pidato Pengukuhan Jabatan Guru Besar pada Fakultas Hukum Universitas Brawijaya, Malang, 2007.

Rahardjo, Satjipto, Masalah Penegakan Hukum, Sinar Baru, Bandung, 1983.

Sadhi Astuti, Made, Hukum Pidana Anak dan Perlindungan Anak,Universitas Negeri Malang, 2003.

Sadjijono, Hukum Kepolisian, Perspektif Hukum dan Hubungannyan dalam Hukum Administrasi, Laks Bang, Jakarta, 2006.

Sri Supatmi Purnianti, Mamik, dan Ni Made Martini Tinduk, Analisa Sistem Peradilan Pidana Anak (Juvenile Justice System) di Indonesia, UNICEF, Indonesia, 2003. 
Suhartono, Slamet, Vage Normen Sebagai Dasar Tindakan Hukum Tata Usaha Negara, Disertasi Program Doktor Ilmu Hukum Fakultas Hukum Universitas Brawijaya, Malang, 2009.

Jawa Pos, 17 April 2007.

Jawa Pos, 23 Juli 2009.

Jawa Pos, 27 Juli 2009.

http://www.arnellaw.com/CM/Custom/TOCJuvenileCrimeCaseSummaries.asp. www.kompas.com./-cetak/0310/08/nasional/611424.htm, Rabu, 28 Oktober 2003. www.pikiran-rakyat.com/cetak/2006/022006/23/1001.htm. 
